\title{
PORCINE STRESS SYNDROME (PSS) IN MANGALITSA PIGS
}

\author{
N. Stanišić ${ }^{1}$, S. Aleksić ${ }^{1}$ L. Di ${ }^{2}$ Z. Stanimirović ${ }^{3}$, G. Zhenhua ${ }^{2}$, M. \\ Petrović $^{4}$, N. Delić ${ }^{1}$, Č. Radović ${ }^{1}$, N. Parunović ${ }^{5}$, M. Gogić ${ }^{1}$ \\ ${ }^{1}$ Institute for Animal Husbandry, Autoput 16, 11080, Belgrade-Zemun, Republic of Serbia \\ ${ }^{2}$ Heilongjiang Academy of Agriculture Sciences, Xuefu road, 150086, Harbin, People Republic of \\ China \\ ${ }^{3}$ Faculty of veterinary medicine, University of Belgrade, Bul. Oslobođenja 18, Belgrade, Republic of \\ Serbia \\ ${ }^{4}$ Faculty of Agriculture, University of Belgrade, Nemanjina 6, 11080 Zemun, Republic of Serbia \\ ${ }^{5}$ Institute of Meat Hygiene and Technology, Kaćanskog 13, 11000, Belgrade, Republic of Serbia \\ Corresponding author: nikola0135@yahoo.com \\ Communication
}

Abstract: Porcine stress syndrome (PSS) is one kind of molecular genetics defect which will cause malignant hyperthermia syndrome in pigs. It was reported that mutation of pig rynodine receptor (RYR1) gene is the main reason for PSS. The aim of this study was to test the RYR1 genotype of 10 Mangalitsa pigs using a polymerase chain reaction-restriction endonuclease fragment length polymorphism (PCR-RFLP) technique, which is a reliable and simple method for RYR1 gene testing. Extraction of DNA was done by using hair follicles. The results showed that the RYR1 genotype of all the 10 porcine cases were negative. These results suggested that Mangalitsa pig could be one of the porcine breeds selectively bred for medical and clinically experiments.

Key words: Porcine stress syndrome gene; RYR1, PCR-RFLP; Mangalitsa pig

\section{Introduction}

Meat is one of the main sources of protein in the human diet and pork is one of the most produced and consumed worldwide. One of the main economic losses in the pig industry is related to PSE (Pale Soft Exudative) pork, which originates from animal stress and depends upon pig genetics and animal handling conditions before and during slaughtering. Stress conditions can activate malignant hyperthermia in pigs homozygous for the PSS (Porcine Stress Syndrome) and may even cause death (Fisher et al., 2000). The candidate gene for PSS, also called halothane gene ( $\mathrm{Hal}$ gene), encodes the precursor protein of the calcium release channel of skeletal muscle sarcoplasmic reticulum (Fujii et al., 1991). Since PSS 
gene carriers have a higher probability of presenting poor quality pork (Hamilton et al., 2000), there is a constant concern about pig welfare during handling and transport before slaughter (Geers et al.,1994).

It was reported that mutation of pig rynodine receptor (RYR1) gene is the main reason for PSS. RYR1 gene was selected as a candidate gene because point mutation at RYR1 locus causing PSS is economically serious problem in swine industry. RYR1 is the calcium release channel of the sarcoplasmic reticulum in skeletal muscle whose contraction, relaxation and energy metabolism are regulated by the concentration of intracellular $\mathrm{Ca}^{2+}$ (MacLennan and Phillips, 1992).

Breeding of domesticated animals for food production historically was directed to increase productive performances. This way highly selected, meat-type pig breeds were developed. Lundstrom et al. (1995) showed that the PSS gene affected the quality of the M. longissimus dorsi and resulted in less tender, less desirable pork. This condition causes the carcasses to be classified as unacceptable. There is a greater drip in the cooler and moisture loss, causing the meat to be very dry when cooked. Stress positive animals tend to consume less feed per day while still converting that feed to lean muscle tissue very efficiently.

In recent years, there has been increasing interest in autochthonous breeds, and not only in regard to their gene preservation (Stevanovic et al., 2009, 2010) but also in their meat products manufactured in traditional way. Mangalitsa, a Serbian autochthonous pig breed, is a typical lard type pig which contains approx. 30-35\% of meat in carcass sides (Petrović et al., 2010).

The aim of this study was to determine the presence of PSS gene in Mangalitsa, a Serbian autochthonous pig breed. Extraction of DNA was done from a hair root that can be a valuable source of DNA for genotyping.

\section{Materials and Methods}

The research was conducted on 10 pigs of Mangalitsa breed. Hairs with roots were pulled from swines reared in farms in Institute for Animal Husbandry in Belgrade, Serbia. PCR-RFLP analyses were done in the Laboratory of Animal Husbandry Research Institute of Heilongjiang academy of Agriculture Sciences in Harbin, China. DNA was extracted from the hair roots. The PCR-RFLP genotyping of the swine RYR1 gene was done in three steps:

1. DNA extraction: Three pieces of hair were washed with $90 \%$ ethil-alcohol and sterilized water. After air drying, hair root portions $(0.5 \mathrm{~cm}$ in length from the root end) were placed in a $1.5 \mathrm{ml}$ microcentrifuge tube where $500 \mu 1$ of $5 \%$ Chelex-100 solution $(100 \mathrm{ml}$ sterilized water $+5 \mathrm{~g}$ Chelex-100) were added. The solution was incubated at $56^{\circ} \mathrm{C}$ for 60 minutes. After vortexing, the tubes were put in the waterbath at $97^{\circ} \mathrm{C}$ for another 30 minutes. Than the sample tubes were stored at $4{ }^{\circ} \mathrm{C}$, before PCR reaction was performed. 
2. PCR-RFLP: $10 \mu \mathrm{l}$ of solution was transferred to another $1.5 \mathrm{ml}$ microcentrifuge tube and used for PCR amplification. A fragment of the RYR1 gene was amplified by PCR using specific primers (RYR1 F: 5'GGAGGGTTCTAAGCTCTGGG3', RYR1 R: 5'TGACCCCTAGGTGCTGGAT3'). The PCR amplification reactions of $20 \mu \mathrm{l}$ total volume in each reaction were performed as follows: $2.0 \mu \mathrm{l}$ of 10xPCR Buffer, $0.6 \mu 1$ of dNTP Mixture $(2.5 \mathrm{pmol} / \mu \mathrm{l}), 0.5 \mu \mathrm{l}$ of RYR1 F (5 $\mathrm{pmol} / \mu \mathrm{l}), 0.5 \mu \mathrm{l}$ of RYR1 R (5 pmol/ $\mu \mathrm{l}), 1.0 \mu \mathrm{l}$ of genomic DNA $(25 \mathrm{ng} / \mu \mathrm{l})$

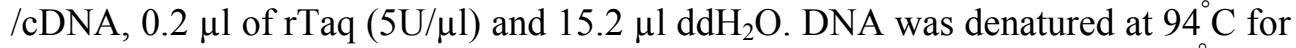
$5 \mathrm{~min}$, then Taq polymerase was added and reactions were performed at $94^{\circ} \mathrm{C}$ for $30 \mathrm{sec}$, at $55^{\circ} \mathrm{C}$ for $30 \mathrm{sec}$ and at $72^{\circ} \mathrm{C}$ for $1 \mathrm{~min}$ in the first 30 cycles, followed by incubation at $72^{\circ} \mathrm{C}$ for $5 \mathrm{~min}$ and at $4{ }^{\circ} \mathrm{C}$ for 10 min using a DNA thermal cycler (Biometra, Germany). The PCR products of RYR1 gene (186 bp long) were digested with restriction endonuclease HhaI at $37^{\circ} \mathrm{C}$ for $2 \mathrm{~h}$ and then fragments were separated using agarose gel electrophoresis. All used solutions were from TAKARA company, Japan.

3. Electrophoresis and detection of PCR products: $10 \mu$ of PCR product was loaded on the gel. PCR product use 1\% gel to run agarose gel electrophoresis, and endonuclease product use 5\% gel to run agarose gel electrophoresis. The ladder of PCR products was separated at a constant voltage of 120-140. The digested DNA fragments were visualized by staining with ethidium bromide $(2 \mu \mathrm{g} / \mathrm{ml})$ and exposure to ultraviolet light.

\section{Results}

All the analysed samples gave PCR products (Fig. 1). In the Figure 2 the PCR amplification products of RYR1 gene was shown. After cutting the PCR products (186bp) with HhaI, two pieces were obtained (125 bp and $61 \mathrm{bp}$ ). That indicates that RYR1 gene is the dominant homozygous in all tested samples and therefore the tested animals phenotype was PSS negative.

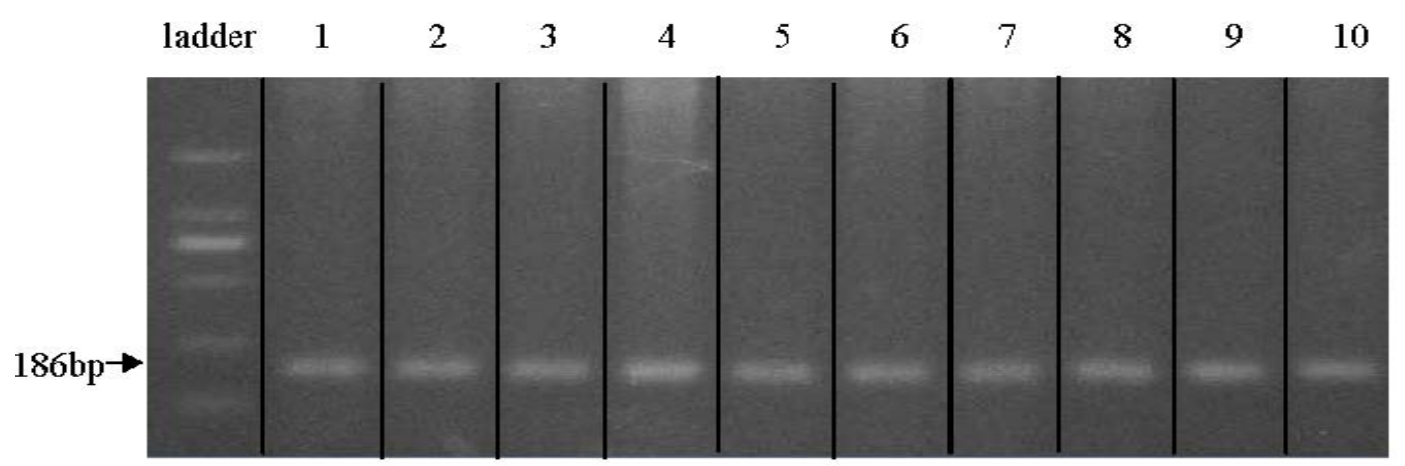

Fig. 1. Ethidium bromide stained agarose gels showing PCR products of RYR1 gene. 


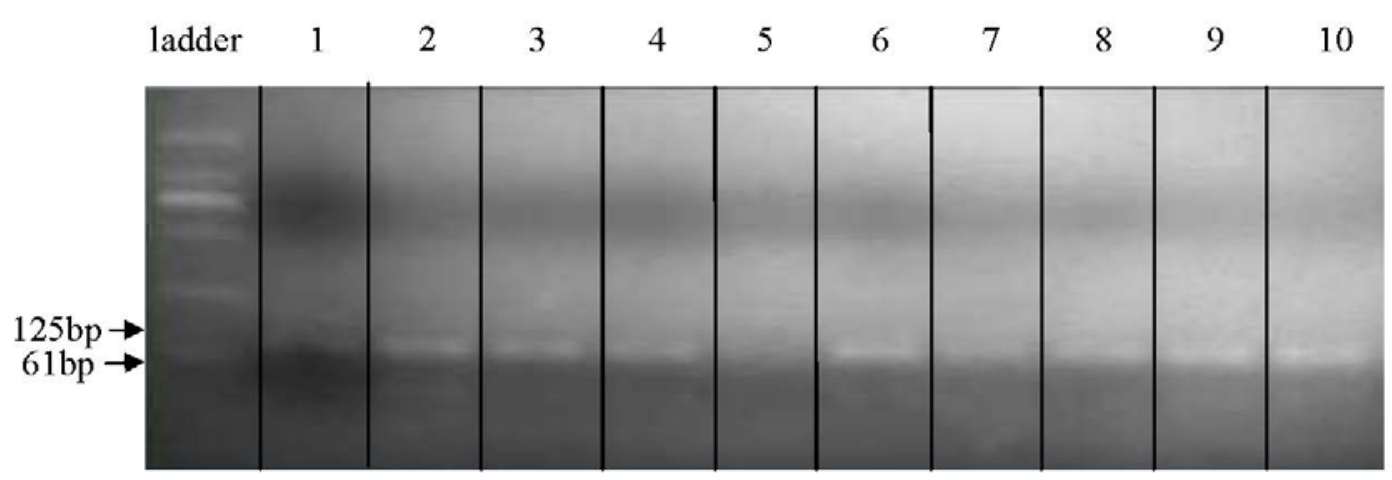

Fig. 2. Results of RFLP analysis of RYR1 gene segment digested with the restriction endonuclease HhaI.

\section{Conclusion}

Porcine stress syndrome is an important economic problem in the pork industry. Upon experimental observation it can be concluded that the genotype of Mangalitsa pig breed was PSS negative. These suggested that Mangalitsa pig could be one of the porcine strains selectively bred for medical and clinical experiments.

\section{Acknowledgements}

This research was a part of the Bilateral Project No. 1-9: Investigation of genetic markers in livestock and poultry, funded by the Ministry of education and science of the Republic of Serbia and Ministry of science of the People Republic of China, and a part of the project TR-31081 financed by the Ministry of Education and Science, Republic of Serbia.

\section{Prisustvo stres sindroma (PSS) kod svinja rase mangulica}

N. Stanišić, S. Aleksić, L. Di, Z. Stanimirović, G. Zhenhua, M. Petrović, N. Delić, Č. Radović, N. Parunović, M. Gogić

\section{Rezime}

Stres sindrom svinja (PSS - Porcine Stress Syndrome) pripada genetskim oboljenjima svinja i može da izazove sindrom maligne hipertermije. Utvrđeno je da 
je mutacija rijanodin receptora (RYR1) gena svinja glavni razlog za pojavu PSS-a. Cilj ovog ogleda bio je testiranje RYR1 gena na 10 svinja rase mangulica korišćenjem PCR-restriktivnog endonukleaza testa (PCR-RFLP), koji pretstavlja jednostavnu i pouzdanu tehniku za testiranje RYR1 gena. Ekstrakcija DNK je obavljena korišćenjem korena dlake svinja. Rezultati ogleda potvrđuju da je RYR1 genotip kod svih 10 svinja bio negativan. $\mathrm{Na}$ osnovu napred navedenog može se zaključiti da bi mangulica mogla da bude jedna od genotipova koji se koriste za medicinska i klinička ispitivanja.

\section{References}

FISHER P., MELLETT F.D., HOFFMAN L.C. (2000): Halothane geno-type and pork quality. 1. Carcass and meat quality traits from the three halothane genotypes. Meat Science, 54, 97-105.

FUJII J., OTSU K., ZORZATO F., DE LEON S., KHANNA V.K., WEILER J.E., O'BRIEN P.J., MACLENNAN D.H. (1991): Identification of a mutation in the porcine ryanodine receptor associated with malignant hyperthermia. Science, 253, 448-451.

GEERS R., BLEUS E., VAN SCHIE T. (1994): Transport of pigs different with respect to the halothane gene: Stress assessment. Journal of Animal Science, 72, 2552-2558.

HAMILTON D.N., ELLIS M., MILLER K.D., MCKEITH F.K., PARRET D.F. (2000): The effect of the Halothane and Rendement Napole genes on carcass and meat quality traits of pigs. Journal of Animal Science, 78, 2862-2867.

LUNDSTROM K., KARLSSON A., HAKANSSON J., HANSSON I., JOHANSSON M., ANDERSSON L., ANDERSSON K. (1995): Production, carcass, and meat quality traits of F2-breed crosses between European wild pigs and domestic pigs including halothane gene carriers. Animal Science, 61, 325-331. MACLENNAN D.H., PHILLIPS M.S. (1992): Malignant hyperthermia. Science, 256, 789-793.

PETROVIĆ M., RADOVIĆ Č., PARUNOVIĆ N., MIJATOVIĆ M., RADOJKOVIĆ D., STANIŠIĆ N. (2010): Fermented sausage made of pig meat from Mangalitsa and Moravka breed. Biotechnology in Animal Husbandry, 26, Spec. Issue. 81-94.

STEVANOVIĆ J., STANIMIROVIĆ Z., DIMITRIJEVIĆ V., MALETIĆ M. (2010): Evaluation of 11 microsatellite loci for their use in paternity testing in the Yugoslav Pied cattle (YU Simmental cattle). Czech Journal of Animal Science, 55 (6), 221-226.

STEVANOVIĆ J., STANIMIROVIĆ Z., DIMITRIJEVIĆ V., STOJIĆ V., FRATRIĆ N., LAZAREVIĆ M. (2009): Microsatellite DNA polymorphism and its 
usefulness for pedigree verification in Simmental cattle from Serbia. Acta Veterinaria, 59 (5-6), 621-631.

Received 15 September 2012; accepted for publication 20 November 2012 